\title{
ETYKA TADEUSZA CZEŻOWSKIEGO WOBEC KULTURY NOWYCH MEDIÓW
}

\section{Tadeusz Czeżowski's Ethics towards New Media Culture}

S u m m a r y: This paper seeks to answer the question whether Tadeusz Czeżowski's concept of ethics and value theory can be useful in a culture whose shape is largely determined by new media. On the basis of the collected arguments, it is argued that certain elements of Czeżowski's system may help to solve some problems arising in this context. The first is the imbalance between real and virtual experience. An ontological exercise is proposed here. The second is setting the mind on permanent, mediated communication. Axiological exercises are the remedy. The third problem is the loss of holistic experience of self and the world. Philosophical exercises based on general concepts may be helpful here.

Ke y w o r d s: Tadeusz Czeżowski, ethics, axiology, new media culture, iGen

\section{Wprowadzenie}

Przyjmuję, że kluczowymi aspektami określającymi kształt kultury są rodzaj, zakres i sposób używania mediów. Z tego punktu widzenia zasadniczą zmianę kulturową spowodowało wprowadzenie medium obrazu, a następnie pisma alfabetycznego. Daleko idące przekształcenia w tej sferze są pochodną zastosowania technologii druku. Był to początek tekstualizacji świadomości całych społeczeństw. Korzystanie $\mathrm{z}$ tych mediów doprowadziło m.in. do ukształtowania zdolności do krytycznego

${ }^{1}$ Dr hab. Wacław Branicki - prof. AGH, Katedra Studiów nad Kulturą i Badań Ery Cyfrowej, Wydział Humanistyczny, Akademia Górniczo-Hutnicza. Adres do korespondencji: ul. Antoniego Gramatyka 8A, 30-071 Kraków; e-mail: branicki@agh.edu.pl. 
myślenia i refleksji. Człowiek mógł także uwolnić się od magicznego postrzegania rzeczywistości. Dzięki temu narodziła się świadomość historyczna².

Do istoty nowych mediów należą interaktywność oraz wirtualność, które dzięki coraz doskonalszej technologii umożliwiają doświadczenie głębokiej immersji ${ }^{3}$. Obserwujemy kolejną refigurację kultury, która jest wynikiem upowszechnienia mediów cyfrowych ${ }^{4}$. Podstawowym czynnikiem tej głębokiej zmiany jest technologia, która umożliwia permanentny dostęp do sieci internetowej. $Z$ tego powodu symbolem tej refiguracji jest smartfon. Jean $\mathrm{M}$. Twenge analizując dane gromadzone od wielu lat, dostrzegła, że w 2012 roku nastapiła istotna zmiana w zachowaniach młodych osób. Właśnie w tym czasie smartfon stał się przedmiotem powszechnie dostępnym w społeczeństwie amerykańskim. Te obserwacje skłoniły Twenge do wprowadzenia nazwy iGen denotującej nowe pokolenie. Amerykańska uczona pisze: „iGen z powodu popularności smartfonów odróżnia się przede wszystkim sposobami spędzania czasu. Codzienne doświadczenia życiowe przedstawicieli tego pokolenia są radykalnie odmienne od doświadczeń ich poprzedników" ${ }^{5}$. Bardzo wiele danych przytoczonych w tej pracy wskazuje, że faktycznie mamy do czynienia z głęboką refiguracją naszego środowiska kulturowego. Te informacje dotyczą populacji Stanów Zjednoczonych, jednak podobne zjawiska pojawiają się w tych społecznościach, w których upowszechniają się media elektroniczne. Pamiętając o różnicach kulturowych, warto zauważyć, że internet i media społecznościowe mają charakter globalny, dlatego w wielu krajach obserwujemy podobne zmiany.

Aktywność w mediach społecznościowych stanowi ważny element życia bardzo wielu młodych ludzi. Tego rodzaju interakcje nie są jednak ekwiwalentne w porównaniu do relacji bezpośrednich ${ }^{6}$. Istnieją istotne przesłanki wskazujące na to, że intensywne korzystanie z mediów społecznościowych przyczynia się do obniżenia poziomu satysfakcji życiowej. Na przykład badania przeprowadzone w grupie młodych Niemców wskazują, że ograniczenie tego typu praktyk przynosi pozytywne efekty, takie jak zwiększenie zadowolenia z życia, zanik symptomów depresyjnych i zdrowy styl życia ${ }^{7}$. W sferze poznawczej media elektroniczne mogą również powodować poważne problemy. W szczególności deficyt uwagi, która jest

2 Vilém Flusser, Kultura pisma. Z filozofii słowa i obrazu (Warszawa: Wydawnictwo Aletheia, 2018), 251-264.

${ }^{3}$ Por. Paul Levinson, Nowe nowe media (Kraków: Wydawnictwo WAM, 2010), 11-22.

${ }^{4}$ Timothy Binkley, „Refigurowanie kultury”. W: Widzieć, myśleć, być. Technologie mediów, red. Andrzej Gwóźdź (Kraków: Universitas, 2001), 113-143.

${ }^{5}$ Jean M. Twenge, iGen (Sopot: Smak Słowa, 2019), 12-13.

${ }^{6}$ Jean M. Twenge, Brian H. Spitzburg, W. Keith Campbell, „Less in-person social interaction with peers among US adolescents in the $21^{\text {st }}$ century and links to loneliness". Journal of Social and Personal Relationships 6 (2019): 1892-1913.

${ }^{7}$ Julia Brailovskaia, Fabienne Ströse, Holger Schillack, Jürgen Margraf, „Less Facebook use - More well-being and a healthier lifestyle? An experimental intervention study”. Computers in Human Behavior 108 (2020), 1-9. Por. także: Jean M. Twenge, W. Keith Campbell, „Media use is linked to lower psychological well-being: Evidence from three datasets". Psychiatric Quarterly 90 (2019): 311-331. 
podstawą uczenia się̧. Badania polskie wykazały, że dzieci w wieku przedszkolnym, które dłużej korzystały z mediów ekranowych, wykazują niższy stopień aktywności twórczej ${ }^{9}$. Wiele przesłanek wskazuje, że przebywanie w kulturze nowych mediów powoduje istotne zmiany mentalne i behawioralne, szczególnie w grupie osób dorastających i młodych. W tej sytuacji wydaje się potrzebne sprawdzenie, jakie modele wychowawcze mogą skutecznie docierać do osób, dla których wirtualność stanowi równorzędną względem realności lub nawet pierwszoplanową przestrzeń życia.

Pytaniem badawczym jest: czy w sytuacji silnego oddziaływania nowych mediów koncepcja etyki i teorii wartości opracowana przez Tadeusza Czeżowskiego (1889-1981) może być podstawą do stworzenia takiej kultury, w której zachodzi proces kształcenia, dzięki czemu osoby mogą doświadczyć głębokiej i trwałej satysfakcji życiowej. Jako hipotezę przyjmuję, że pewne elementy koncepcji Czeżowskiego mogą stanowić podstawę dla zbudowania takiej kultury w obecnych warunkach cywilizacyjnych. Oznacza to, że bazując na systemie polskiego uczonego, można określić pewien ideał wychowawczy oraz opracować rozwiązania metodyczne pozwalające na zbliżenie się do niego. Tadeusz Czeżowski reprezentuje styl uprawiania nauki charakterystyczny dla szkoły lwowsko-warszawskiej, której był znamienitym przedstawicielem. Poza etyką zajmował się także logiką oraz ontologią ${ }^{10}$.

\section{Dojrzałość jako strategiczny cel kształcenia}

Dojrzałość rozumiem jako stan egzystencjalny osoby, który przejawia się w gotowości do podejmowania decyzji oraz przyjmowania odpowiedzialności za ich konsekwencje. $Z$ tej perspektywy osoby nastoletnie z pokolenia internetu wchodzą $\mathrm{w}$ dorosłość $\mathrm{z}$ opóźnieniem $\mathrm{w}$ porównaniu do poprzednich generacji. Twenge, odnosząc się do populacji Stanów Zjednoczonych, wskazuje, że przejawia się to mniejszą skłonnością do podejmowania pracy (np. w okresie wakacyjnym) oraz do ubiegania się o prawo jazdy. Badani rzadziej podejmują również kontakty seksualne, umawiają się na randki i imprezy w gronie rówieśników. Opóźnił się także czas, w którym młodzi ludzie sięgają po alkohol. Mniejsza liczba zachowań ryzykownych jest korzystna. $Z$ drugiej jednak strony przedłużające się moratorium jest problematyczne. Amerykańska uczona stwierdza, że prędkość rozwoju człowieka zależy od kontekstu kulturowego. Twenge wskazuje, że kluczowymi

\footnotetext{
${ }^{8}$ Por. Manfred Spitzer, Cyfrowa demencja (Słupsk: Dobra Literatura, 2015).

9 Karolina Applet, Marta Jarzembowska, „Aktywność twórcza a korzystanie z urządzeń ekranowych przez dzieci w wieku przedszkolnym”. Psychologia Rozwojowa 2 (2020): 31-42.

${ }^{10}$ Szczegółowe omówienie filozofii Czeżowskiego znajduje się w monografii: Dariusz Łukasiewicz, Filozofia Tadeusza Czeżowskiego (Bydgoszcz: Wydawnictwo Akademii Bydgoskiej im. Kazimierza Wielkiego, 2002).
} 
czynnikami, które spowodowały wydłużenie okresu dzieciństwa, są indywidualizm, czas spędzony przed ekranem oraz permanentna kontrola rodzicielska, którą umożliwił smartfon ${ }^{11}$.

Indywidualizm jest integralnym elementem kultury nowych mediów. Istotnymi cechami tego środowiska są bowiem interaktywność i możliwość wyboru oraz samodzielnego tworzenia i publikowania treści. Ważnym pojęciem ujmującym opisywane zjawisko jest „personalizacja przekazu”. Te okoliczności sprzyjają wytworzeniu przekonania, że to internauta decyduje, jakie treści są warte uwagi. W innym wariancie użytkownik nowych mediów może zgodzić się na przyjęcie zestawu, który został utworzony przez algorytmy, ale za to z przeświadczeniem o wyjątkowości wyrażonym w haśle: „wybrane specjalnie dla ciebie”. Narastający indywidualizm może przekształcić się w narcyzm. Zjawisko to jest destrukcyjne zarówno w wymiarze osobistym, jak też społecznym ${ }^{12}$.

Na podstawie modelu aksjologii Tadeusza Czeżowskiego możliwe jest zbudowanie takiej kultury, w ramach której można prowadzić konkluzywną debatę z zachowaniem szacunku dla jednostkowych decyzji. Jest tak dlatego, że ten system jest otwarty na krytykę: „Być może, iż w moich analizach jest błąd, być może, iż założenia metodologiczne, na których się opieram, ktoś inny odrzuci; nie stawiam swoich stwierdzeń jako dogmatów"13. Polski uczony domaga się jednak krytyki racjonalnej, to znaczy takiej, która bazuje na właściwej interpretacji.

Aksjologia Czeżowskiego nie jest zbiorem gotowych rozwiązań, lecz stwarza możliwość samodzielnej oceny wartości danego zjawiska. Czeżowski nie będąc relatywistą, był zarazem przekonany o „nieustannej ewolucji” systemów etycznych i estetycznych, podobnie jak dzieje się to w odniesieniu do teorii nauk przyrodni$\mathrm{czych}^{14}$. Etyka, czyli domena wartości moralnych, jest w tym ujęciu nauką empiryczną. Nie można zatem domagać się uznania pewnych twierdzeń etycznych bez odpowiednich przesłanek opartych na wielokrotnie zweryfikowanym doświadczeniu. Są nimi w pierwszej kolejności dokonywane intuicyjnie oceny jednostkowych czynów. Te ewaluacje są następnie zbierane, analizowane i poddawane pod dyskusję. Obiektywność twierdzeń etycznych nie jest założeniem, lecz dążeniem. Ocena danego czynu jako dobry lub zły nie jest traktowana jako apodyktyczny werdykt, lecz jako element zbioru danych. Kluczowe jest natomiast „[...] aby oceny były intersubiektywnie komunikowalne i sprawdzalne lub, mówiąc bardziej po prostu, by różni badacze mogli się ze sobą porozumiewać co do tego, jak oceniają i czy oceniają zgodnie"15.

11 Twenge, iGen, 25-57.

12 Więcej na ten temat pisałem w innym miejscu: Wacław Branicki, „Indywidualizm w wybranych środowiskach nowych mediów". Horyzonty Wychowania 24 (2013): 75-91.

${ }_{13}$ Tadeusz Czeżowski, „Uwagi o etyce jako nauce empirycznej”. W: tegoż, Pisma z etyki i teorii wartości (Wrocław: Zakład Narodowy im. Ossolińskich, 1989), 108.

${ }_{14}$ Tenże, „Etyka jako nauka empiryczna”. W: tegoż, Pisma, 104.

15 Tamże, 102. 
System ten ma charakter hipotetyczny, ponieważ jego podstawą są dane empiryczne. Polski uczony pisze: „Nie aprioryczne prawa etyczne, lecz empiryczne oceny pierwotne obejmują rolę założeń etyki” ${ }^{16}$. Przystępujący do formułowania oceny podmiot powinien brać $w$ nawias wszelkie aprioryczne założenia. Na podstawie wielu powtórzeń intuicyjnych ocen różnych wydarzeń określona zostaje ogólna teza o charakterze normatywnym. W zależności od liczby wykonanych ewaluacji wynik końcowy jest mniej lub bardziej prawdopodobny. Jeżeli dochodzi do konfliktu norm sformułowanych na bazie danych empirycznych, wówczas należy zmodyfikować system poprzez zmianę zakresów występujących w nim terminów. Model etyczny jest próbą realizacji w danej grupie teoretycznego systemu. Doświadczenie pojawiające się podczas tej aplikacji powinno stanowić asumpt do korygowania teorii. Proces ten powinien mieć charakter ciągły i progresywny. Dobro jest niezmienne, lecz system teoretyczny jest narzędziem, dzięki któremu możemy tylko do niego się zbliżyć. Analogiczna sytuacja panuje wedle Czeżowskiego w naukach przyrodniczych w odniesieniu do prawdy.

Spróbujmy teraz zastosować ten fragment systemu Czeżowskiego do oceny zjawiska charakterystycznego dla kultury nowych mediów. Manfred Spitzer pisze:

[...] podczas wypadków już nie jest udzielana pomoc, ale ofiary są fotografowane lub filmowane, a zdjęcia i filmy wrzucane do sieci - doprawdy ciężko o mniej empatyczne zachowania! Fakt, że wiosną 2018 roku w Bundestagu dyskutowano prawo penalizujące takie zachowanie, zasadniczo pokazuje, jak niski jest obecnie w Niemczech poziom empatii ${ }^{17}$.

Mamy tu do czynienia ze zjawiskiem, które może stać się przedmiotem dyskusji w grupie nastolatków. Wielu $\mathrm{z}$ nich mogło widzieć tego typu materiały. W opisanej sytuacji może znaleźć się każdy z nas, dlatego sporo osób zapewne szybko zaangażuje się w ocenę tej sytuacji. Wartościowaniu moralnemu podlega także samo oglądanie tego rodzaju treści w mediach. Ocena moralna opisanego przez Spitzera zachowania wydaje się oczywista. Jednak pojawia się pytanie, dlaczego pomimo wysokiej zgodności ocen wiele osób postępuje źle. Zapewne wiele wyjaśnia kontekst społeczno-kulturowy. W pewnych okolicznościach wielu przyzwoitych ludzi zachowuje się niemoralnie. To zjawisko jest przedmiotem namysłu od dawna ${ }^{18}$. Fenomen opisany przez Spitzera wydaje się jednak poważniejszy, ponieważ prawdopodobnie zachowanie tych osób jest uwarunkowane nie tylko przez sytuację, ale także przez zniekształcone przez media ekranowe poczucie realności. Osoby z pokolenia internetu przebywają w sieci

16 Tamże, 101.

17 Manfred Spitzer, Epidemia smartfonów (Słupsk: Dobra Literatura, 2021), 36.

18 Por. np. John M. Darley, Bibb Latané, „Bystander intervention in emergencies: Diffusion of responsibility”. Journal of Personality and Social Psychology 4 (1968): 377-383; Stanley Milgram, „Behavioral study of obedience". Journal of Abnormal and Social Psychology 4 (1963): 371-378; John M. Darley, C. Daniel Batson, „»Z Jerozolimy do Jerycha«. Badanie wpływu zmiennych sytuacyjnych i dyspozycyjnych na udzielanie pomocy”. W: Człowiek istota społeczna. Wybór tekstów, red. Elliot Aronson (Warszawa: WN PWN, 2002), 65-82. 
średnio sześć godzin dziennie, równocześnie znacznie ograniczając kontakty bezpośrednie ${ }^{19}$. Badania wskazują, że permanentna obecność mediów elektronicznych negatywnie wpływa na funkcje poznawcze ${ }^{20}$.

W tej sytuacji adekwatną jest uwaga Czeżowskiego dotycząca kształcenia zmysłu obserwacji. Polski uczony zdawał sobie doskonale sprawę, że w ludzki umysł można relatywnie łatwo zaszczepić wątpliwość w kwestii realnego istnienia rzeczywistości. Wedle tego systemu poza doświadczeniem zmysłowym istnieją także inne jego rodzaje. Wszystkie one mają tę cechę wspólną, że w akcie poznawczym ujmują przedmiot „[...] bezpośrednio - tzn. we własnej jego postaci, nie zaś za pośrednictwem jakichkolwiek znaków - i całościowo [... $]^{21}$. Wedle Czeżowskiego taki akt poznawczy jest rodzajem poznania intuicyjnego. Podstawowym rodzajem intuicji jest ta, która wymaga przyjęcia postawy uważności ${ }^{22}$. Dzięki temu podmiot może stwierdzić, że dany przedmiot istnieje. Taka konstatacja może dokonać się wyłącznie w akcie intuicji, ponieważ istnienie nie jest cechą przedmiotu. Nie można zatem istnienia zobaczyć w przedstawieniu przedmiotu, tak jak można ujrzeć kształt, kolor lub inne jego cechy.

Wiele osób młodego pokolenia doświadcza negatywnych emocji, a nawet poważnych zaburzeń psychicznych $\mathrm{z}$ tego powodu, że spotykają się z wyidealizowanymi wizerunkami swoich rówieśników wykreowanymi w mediach społecznościowych. Porównywanie się do takich fikcyjnych postaci często powoduje obniżenie poczucia własnej wartości oraz stany depresyjne lub zaburzenia narcystyczne ${ }^{23}$. Wobec tego proponowane przez Czeżowskiego ćwiczenie postawy uważności, dzięki której kształtuje się intuicja otwierająca umysł na doświadczenie istnienia, wydaje się bardzo potrzebna. Ma to być doświadczenie nie zapośredniczone przez żadne znaki, czyli żadne media. Przedmiot dany w postrzeżeniu wzrokowym i przedmiot dany w świadomości przez wyobrażenie mogą być nieodróżnialne, jeżeli posiadają ten sam zestaw cech. Takie przedmioty różnią się wyłącznie w zakresie sposobu istnienia. Ten pierwszy istnieje w sposób realny, a drugi intencjonalny.

Wydaje się potrzebne, szczególnie w okresie wczesnej adolescencji, kształcenie w zakresie podstawowych kompetencji w dziedzinie ontologii. Można posłużyć się prostym ćwiczeniem. W pierwszej jego części prosimy uczniów o dokładną obserwację wybranego przedmiotu. W drugiej części prosimy o zamknięcie oczu i szczegółowe wyobrażenie sobie tego przedmiotu. Następnie zadajemy pytania, które mają zainicjować dyskusję: jaka jest różnica pomiędzy przedmiotem pierwszym

19 Twenge, iGen, 61.

20 Spitzer, Epidemia, 59-69.

21 Tadeusz Czeżowski, „Filozofia na rozdrożu”. W: tegoż, Pisma, 39.

22 Czeżowski nie stosował terminu „uważność”, lecz „uwaga”. Użyłem pierwszego pojęcia, które jest stosowane w psychologii, aby podkreślić możliwości praktycznego zastosowania koncepcji polskiego filozofa.

${ }^{23}$ Elias Aboujaoude, Wirtualna osobowość naszych czasów. Mroczna strona e-osobowości (Kraków: WUJ, 2012), 71. Por. także: Renee Engeln, Obsesja piękna. Jak kultura popularna krzywdzi dziewczynki i kobiety (Warszawa: Wydawnictwo Buchmann, 2018). 
i drugim? Jakie cechy posiada przedmiot pierwszy w porównaniu do drugiego? Czym jest istnienie? Jak możemy odróżnić przedmiot istniejący od nieistniejącego? Czym różni się przedmiot realny od wirtualnego? Celem tego typu ćwiczeń jest kształtowanie postawy uważności oraz intuicji egzystencjalnej.

Czeżowski wskazuje, że warto poszerzyć zakres pojęcia „doświadczenie”. Wyróżniamy doświadczenie zmysłowe, estetyczne, moralne oraz introspekcyjne ${ }^{24}$. Przy zachowaniu rygoryzmu naukowego takie ujęcie pozwala wyjść poza wąsko rozumiany scjentyzm. Przedstawione powyżej ćwiczenie ontologiczne może pomóc w kształtowaniu świadomości, że doświadczenie metafizyczne nie jest czymś abstrakcyjnym, ale bardzo podstawowym. W obecnych warunkach tego rodzaju praktyka wydaje się niezbędna dla utrzymania dobrej kondycji psychicznej.

Podstawą dojrzałości osobowej jest zdolność do odróżniania na poziomie doświadczeniowym i konceptualnym sposobów istnienia. Z perspektywy systemu Czeżowskiego deficyt w tym zakresie powoduje ograniczenie doświadczenia odpowiedzialności. Podstawowym czynnikiem powodującym skrajny indywidualizm i narcyzm jest słabe doświadczenie realności. $Z$ tego punktu widzenia szczególnie niekorzystne są interakcje $z$ mediami ekranowymi we wczesnych etapach rozwoju, gdy poczucie realności dopiero się kształtuje. Chodzi tutaj także o posługiwanie się takimi urządzeniami przez rodziców i wychowawców w obecności dzieci ${ }^{25}$.

\section{Uczucia przekonaniowe jako podstawa kompetencji moralnych}

Pokolenie ukształtowane w kulturze nowych mediów stosuje pojęcie bezpieczeństwa osobistego w szerokim zakresie. Poza kwestiami fizycznymi kluczowa jest sfera emocjonalna. Prawdopodobnie wynika to z tego, że znacząca część życia tych osób przeniosła się do przestrzeni wirtualnej, w której nie można zagrozić fizycznie, ale można zranić za pomocą słów oraz milczenia. Twenge pisze, że na uniwersytetach amerykańskich jest tworzona „bezpieczna przestrzeń”, w której studenci mogą odzyskać równowagę emocjonalną. Problem polega na tym, że osoby z pokolenia iGenu mogą odczuwać trudne do zniesienia emocje w wyniku dyskusji, w której pojawiły się niezgodne z ich przekonaniami poglądy. Ograniczenie kontaktów społecznych zmniejsza poziom odporności emocjonalnej, która kształtuje się przez doświadczenie oporu, polemiki, sprzeciwu. Wobec tego należy liczyć się z tym, że podczas dyskusji na temat takich sytuacji, jak np. „fotografowanie wypadku”, może pojawić się opór emocjonalny. Przebywanie

${ }^{24}$ Czeżowski, „Filozofia na rozdrożu”, 39.

${ }_{25}$ Spitzer, Epidemia, 71-90. Por. także: Katarzyna Gołuńska, Magdalena Miotk-Mrozowska, „Znaczenia nadawane urządzeniu dotykowemu przez rodziców małych dzieci w interakcji ja - dziecko - urządzenie mobilne - badanie eksploracyjne”. Psychologia Rozwojowa 2 (2017): 87-110. 
w środowiskach nowych mediów istotnie podnosi ryzyko zaburzeń emocjonalnych, głównie nerwicowych i depresyjnych ${ }^{26}$. Omawiając gwałtowny wzrost tych zjawisk, Twenge pisze: „Nie jest to już zwykła fala, ale prawdziwe tsunami”27.

Etyka Czeżowskiego nie jest emotywistyczna, może jednak stanowić podstawę do kształtowania uczuć. Jest to możliwe, ponieważ właściwa ocena danego wydarzenia jest dokonywana na poziomie intelektualnym. Emocje kojarzone z tą sytuacją wynikają bezpośrednio z aktywności racjonalnej. Dotyczy to jednak wyłącznie emocji przekonaniowych, ale już nie doznaniowych.

To, czy reakcja emocjonalna podmiotu ma charakter doznaniowy, czy przekonaniowy, zależy od przygotowania intelektualnego. Model polskiego etyka stwarza możliwość kształcenia refleksyjnych emocji poprzez ćwiczenia aksjologiczne. Czeżowski pisze: „[...] ocena wartości jest warunkiem koniecznym pojawienia się przeżycia emocjonalnego, sama zaś może pojawić się bez niego [...]"28. Przez „przeżycie emocjonalne” rozumiem tutaj zjawisko, którego istota jest dana w świadomości. Ponadto podmiot może uchwycić związek pomiędzy dokonaną oceną a jej reprezentacją emocjonalną. Tego rodzaju praktyka prowadzi do „semantycznego nasycenia" emocji. Nabierają one głębszego znaczenia dla podmiotu. Dzięki temu jednostka zyskuje realny wpływ na swój stan emocjonalny i w pewnym zakresie także fizjologiczny. Badania prowadzone przez Georga Linda potwierdzają, że poprzez ćwiczenia polegające na nadawaniu ocen etycznych oraz prowadzenie dyskusji na ten temat powodują wzrost kompetencji moralnych ${ }^{29}$.

System Czeżowskiego może być podstawą do kształcenia emocji przekonaniowych. Znajdujemy tutaj bardzo przydatną w praktyce dystynkcję. Polski uczony podzielił uczucia na doznaniowe oraz przekonaniowe. Przykładem pierwszego jest strach. Podstawą psychologiczną strachu są dwa zbiory wrażeń. W pierwszym znajdują się wrażenia zmysłowe pochodzące od przedmiotu zewnętrznego. W drugim są natomiast wrażenia ustrojowe, to znaczy takie, które pochodzą z organizmu. Mogą być one związane np. z przyspieszoną akcją serca, spłyconym oddechem itp. ${ }^{30} \mathrm{Nie}-$ którzy badacze współcześni uważają, że emocje reprezentują stany cielesne. W takim ujęciu ciało reaguje na bodziec zewnętrzny, a przedmiotem emocji jest jedynie stan organizmu. Emocje są tutaj wprost traktowane jako postrzeżenia zmian cielesnych ${ }^{31}$.

${ }^{26}$ Por. Sei Yon Sohn, Philippa Rees, Bethany Wildridge, Nicola J. Kalk, Ben Carter, „Prevalence of problematic smartphone usage and associated mental health outcomes amongst children and young people: A systematic review, meta-analysis and grade of the evidence". BMC Psychiatry 1 (2019): 356.

27 Twenge, iGen, 115.

${ }^{28}$ Tadeusz Czeżowski, „Uwagi o etyce jako nauce empirycznej”. W: tegoż, Pisma, 107.

${ }^{29}$ Georg Lind, How to Teach Moral Competence (Berlin: Logos Verlag, 2019).

${ }^{30} \mathrm{Za}$ odpowiedznik podziału emocji na doznaniowe i przekonaniowe można uznać potwierdzoną empirycznie dystynkcję wyróżniającą emocje automatyczne i refleksyjne. Por. Maria Jarymowicz, Kamil Imbir, „O dynamice emocji wzbudzanych automatycznie bądź refleksyjnie”. W: Dynamika emocji. Teoria i praktyka, red. Dariusz Doliński, Wojciech Błaszczak (Warszawa: WN PWN, 2011), 13-20.

${ }^{31}$ Jesse J. Prinz, „Emocje jako ucieleśnione oceny”. W: Formy aktywności umysłu. Ujęcia kognitywistyczne. Emocje, percepcja, świadomość, red. Andrzej Klawiter (Warszawa: WN PWN, 2008), 45. 
W ujęciu Czeżowskiego na podstawie psychologicznej konstytuuje się uczucie, które posiada specyfikę dzięki charakterystycznym wrażeniom cielesnym. Model ten zawiera również taki wariant, w którym pojawia się uczucie bez wrażeń zmysłowych. Nie może natomiast zaistnieć sytuacja, w której uczucie powstaje bez odpowiednich wrażeń pochodzących z organizmu. Przedmiotem uczuć doznaniowych nie są przedmioty zewnętrzne. W tym znaczeniu nie są one obiektywne. Na przykład przedmiotem uczucia nieprzyjemności nie jest ukłucie, które je spowodowało, lecz wrażenie bólu, na bazie którego ta emocja powstała.

Uczucia przekonaniowe mają natomiast przedmiot w świecie zewnętrznym. Emocja ta oprócz dwóch rodzajów wrażeń zawiera także przedstawienie przedmiotu, przekonanie stwierdzające jego istnienie oraz ocenę przypisującą wartość etyczną lub estetyczną. Jako przykład uczucia przekonaniowego podaje Czeżowski lęk. Podstawa psychologiczna strachu i lęku jest taka sama. Można więc orzec, że lęk jest bardziej złożoną, wysublimowaną postacią strachu.

Dla praktyki kształcenia uczuć kluczowe jest twierdzenie Czeżowskiego: „Przedstawienie przedmiotu wraz z przekonaniem dotyczącym jego istnienia i oceną wartości wchodzi w miejsce bodźca wywołującego pierwotne uczucie doznaniowe i wzbudza pozostałe składniki uczucia, tj. wrażenia ustrojowe wraz z dołączającą się do nich jakością uczuciową przyjemności lub przykrości [...]”32. Podstawą sublimowania emocji jest zatem umiejętność kształtowania wyraźnego przedstawienia przedmiotu przy wykorzystaniu materiału wrażeniowego. Uczucie doznaniowe bazuje na zbiorze wrażeń pozbawionych „wyraźnej jakości postaciowej”. Praca zaczyna się od uważnej obserwacji. Po pewnym czasie ze zbioru wrażeń wyłania się kształt, czyli postać przedmiotu.

Drugim punktem są ćwiczenia ontologiczne ${ }^{33}$. Czy to, co widzę, jest realne? Czy to, co widzę, jest realne dla mnie? Czy to, co widzę, może przydarzyć się mnie? Czy mogę być podmiotem czynu, który poznaję? W trzecim etapie należy przypisać ocenę etyczną lub estetyczną temu, co podmiot percypuje. Dzięki temu może ulec zmianie pierwotna emocja. Czeżowski wprowadza ważną dystynkcję: „Trzeba odróżnić jakość dodatnią lub ujemną uczucia wartości, o której mowa od wartości, którą przypisujemy samemu uczuciu, gdy oceniamy je jako dobre lub złe" ${ }^{\text {"34 }}$. Na tej podstawie polski uczony stwierdza, że np. zazdrość ma znak dodatni jako uczucie wartości, ale ujemny jako uczucie. Oznacza to, że przedmiot, którego ktoś zazdrości, jest cenny, ale samo uczucie zazdrości jest negatywne. Odwrotna sytuacja zachodzi w przypadku uczucia litości, natomiast gniew ma wartość ujemną w obydwu wymiarach.

${ }^{32}$ Tadeusz Czeżowski, „Strach i lęk (przyczynek do klasyfikacji uczuć)”. W: tegoż, Pisma, 214.

${ }^{33}$ Pojęcie ćwiczeń ontologicznych nie było używane przez Czeżowskiego. Jest to termin, który wprowadziłem, aby wskazać na możliwości praktycznego zastosowania pewnych elementów koncepcji polskiego filozofa.

${ }^{34}$ Tadeusz Czeżowski, „Uczucia i dążenia”. W: tegoż, Pisma, 262. 
Dzięki stosowaniu tego rozróżnienia podmiot może rozwijać intuicję aksjologiczną. Człowiek nie utożsamia się wówczas ze swoimi emocjami, lecz traktuje je jako media dostarczające informacje. Taką wiadomość należy w sposób umiejętny, krytyczny odczytać. Na przykład uczucie zazdrości może stać się destrukcyjne. Kiedy natomiast zostaje odczytane jako informacja o istnieniu pewnego wartościowego przedmiotu, może stać się ważnym impulsem rozwojowym. Takie podejście pozwala także docenić takie emocje, jak zazdrość. Nawet jeżeli z punktu widzenia moralnego jest ono oceniane jako nieszlachetne, to z perspektywy poznawczej może być bardzo cenne dla podmiotu. Taka świadomość ułatwia przyjęcie i wytrzymanie takiego nieprzyjemnego stanu emocjonalnego bez natychmiastowych konsekwencji behawioralnych.

Czeżowski zauważa w tekście z 1943 roku, że od pewnego czasu w kulturze zaczęła dominować ekspresywna funkcja języka. Oznacza to, że słowa w mniejszym stopniu służą do oznaczania rzeczy, a w większym do wyrażania przeżyć. W kulturze nowych mediów skłonność osób do szybkiej ekspresji przeżyć jest charakterystyczna. Sherry Turkle zauważa, że w tych warunkach kształtuje się zdolność do przeżywania uczuć tylko wówczas, gdy są one komunikowane. Następuje zatem zamiana postawy wyrażonej w twierdzeniu: „chcę/muszę wyrazić to, co czuję” na postawę „chcę przeżywać emocje, dlatego wyrażam"35. Czynnikiem umożliwiającym tę zmianę jest zdolność do ciągłej komunikacji. Świadomość ludzi funkcjonujących w kulturze nowych mediów jest nieustannie nastawiona na ten modus. Tę postawę można wyrazić w twierdzeniu: "aby coś naprawdę przeżyć, muszę to sfotografować, sfilmować i zakomunikować”. Skrajną ilustracją tego zjawiska jest sytuacja opisana przez Spitzera: filmowanie wypadku. Pierwszorzędnym celem takiego działania wydaje się właśnie wyrażenie i przeżycie uczuciowe, a nie dokumentacja zdarzenia. Medialna funkcja oznaczania rzeczywistości jest wypierana przez funkcję ekspresywną.

Znacząco większa skala zaburzeń emocjonalnych w pokoleniu internetu jest przesłanką podnoszącą prawdopodobieństwo tezy, że przewaga ekspresji emocjonalnej nie jest czynnikiem korzystnym. W ramach modelu Czeżowskiego można orzec, że tego rodzaju emocje są dosłownie bezwartościowe. Jest tak dlatego, że brakuje w nich przekonania o istnieniu przedmiotu oraz oceny, która określa jego wartość. Według polskiego filozofa autentyczna emocja zawsze jest niejako nadbudowana na tych elementach. Ekscytacja wywołana przez komunikację wydaje się jedynie reakcją organizmu. Uczucie, które pojawia się na tej bazie, zgodnie z terminologią Czeżowskiego ma charakter doznaniowy.

Dla kształcenia dojrzałości emocjonalnej kluczowe jest zatem ćwiczenie postawy aksjologicznej poprzez nadawanie wartości pojedynczym przypadkom. Polski etyk porównuje tę praktykę do nabierania biegłości w prowadzeniu obserwacji naukowej. Dzięki doskonaleniu uważności podmiot może stwierdzić istnienie i opisać

35 Sherry Turkle, Samotni razem. Dlaczego oczekujemy więcej od zdobyczy techniki, a mniej od siebie nawzajem (Kraków: WUJ, 2013), 221. 
cechy przedmiotu. Poprzez ćwiczenie intuicji moralnej może stwierdzić, jaka jest wartość etyczna danego zjawiska. Emocje, które powstają na takiej podstawie, są bardziej szlachetne.

\section{Sens życia w kulturze nowych mediów}

Kiedy Laura Santos zauważyła, że wielu studentów uniwersytetu Yale jest niezadowolonych ze swojego życia, postanowiła opracować kurs „The Science of Well-Being”36. Jedną z głównych przyczyn takiej postawy młodych ludzi jest przecenianie wartości ekonomicznych i niedocenianie poszukiwań mądrej filozofii życia. Dla większości studentów amerykańskich (82\%) ważne jest osiągnięcie wysokiego statusu ekonomicznego. Jedynie $47 \%$ osób z tej grupy uznało za ważne realizowanie mądrej filozofii życia ${ }^{37}$. Wartości ekonomiczne poprawiają dobrostan tylko w pewnym zakresie. Badania potwierdzają natomiast, że można osiągnąć satysfakcję życiową, kierując się filozofią minimalizmu, której podstawą jest przyjęcie pewnego przekonania i ukształtowanie wedle niego emocji ${ }^{38}$. Chociaż obawy pokolenia internetu o bezpieczeństwo ekonomiczne są uzasadnione, jednak niewłaściwe podejście do tego problemu odbiera radość życia.

Z modelem Czeżowskiego pozostaje kompatybilnych wiele przydatnych w tym kontekście ćwiczeń stoickich. Na przykład w ujęciu Seneki praktyka myślowa dotycząca wartości ekonomicznych ma taką postać: „jeżeli przekonasz sam siebie, że nawet bez majątku będziesz mógł żyć szczęśliwie, jeżeli zawsze będziesz patrzył nań jako na rzecz mającą umknąć" ${ }^{39}$. Podstawą jest zatem występujące również w systemie Czeżowskiego ćwiczenie ontologiczne. Przekonanie o istnieniu i naturze rzeczy zostaje ukształtowane na podstawie uważnej obserwacji. W drugim punkcie następuje ocena wartości tych przedmiotów. Mają one charakter nietrwały, a ich przynależność może zostać zmieniona w wyniku niezależnej od jednostki koniunktury. $Z$ tych powodów ich wartość dla podmiotu jest relatywnie niska. Bardziej wartościowe jest to, na co osoba ma bezpośredni wpływ. Taka wartość, która nie może być jej tak łatwo odebrana, jak to jest w przypadku dóbr materialnych. Polski etyk sformułował sentencję: „Każde nowe pragnienie czyni cię zależnym od wszystkich, którzy mogą się mu przeciwstawic" "40. Z tego punktu widzenia majątek nie jest złem dla człowieka, ale jest nim jego pragnienie, ponieważ czyni go

${ }^{36}$ https://www.coursera.org/learn/the-science-of-well-being. Kurs cieszy się dużą popularnością, a badania potwierdziły, że uczestnicy nabywają skuteczne kompetencje umożliwiające poprawę satysfakcji życiowej. Por. David B. Yaden, Jennifer Claydon, Meghan Bathgate, Belinda Platt, Laurie R. Santos, „Teaching well-being at scale: An intervention study". PLoS ONE 16(4) (2021).

37 Twenge, iGen, 190.

${ }^{38}$ Kasey Lloyd, William Pennington, „Towards a theory of minimalism and wellbeing”. International Journal of Applied Positive Psychology 5 (2020): 121-136.

39 Seneka, Myśli (Kraków: Wydawnictwo Literackie, 1987), 391.

40 Tadeusz Czeżowski, „Aforyzmy”. W: tegoż, Pisma, 286. 
niewolnikiem. Czeżowski pisze: „Strach i nienawiść to uczucia niewolnika w stosunku do władcy - niegodne wolnego człowieka" ${ }^{41}$. W przypadku posiadacza jest to strach przed utratą oraz nienawiść wobec tych, którzy mogą odebrać, lub wobec tych, którzy posiadają więcej.

Sens życia Czeżowski porównuje do zdania. Może być ono spójne lub niespójne. Jest to uzależnione od składni logicznej. Życie osoby staje się sensowne wówczas, gdy podejmowane działania są realizowane w odniesieniu do strategicznego celu. W tym aspekcie wyraża się absolutyzm etyczny polskiego filozofa. Jan Woleński pisze: „Czeżowski był obiektywistą (wartości są obiektywne) i absolutystą; dobro jest jedno i bezwzględne, ale istnieją różne rzeczy dobre [...]"42. Określenie misji życiowej jest warunkiem koniecznym, choć nie wystarczającym. Jeżeli bowiem wskazuje Czeżowski - ktoś podporządkowuje swoje wysiłki kolekcjonowaniu bezwartościowych przedmiotów, nie sposób uznać takiego postępowanie za sensowne, choć jest celowe. W tym aspekcie ujawnia się wspomniany przez Woleńskiego obiektywizm aksjologiczny. Wartościowe jest tylko to, co faktycznie jest takim. Podmiot nie posiada w tym zakresie mocy sprawczej. Polski etyk pisze: „życie ma sens, jeżeli zostało tak ułożone, iż tworzy całość zmierzającą rozumnie ku zrealizowaniu celów najlepszych z tych, do których zrealizowania w danych warunkach jesteśmy zdolni” ${ }^{43}$. Fenomen sensu jest zatem ejdetycznie związany z wartością. Do rozpoznawania adekwatnej wartości celu niezbędne jest kształcenie umiejętności zwanej mądrością życiową. W połączeniu z silną wolą tworzy ona charakter etyczny. Posiadanie takiego charakteru wedle Czeżowskiego jest koniecznym warunkiem nadania sensu swojemu życiu ${ }^{44}$.

Scharakteryzowany powyżej sens nazywa polski uczony wewnętrznym. Poza tym wyróżnia sens społeczny, który rozpoznajemy poprzez długotrwałe skutki działalności autora. Szczególnie interesujący jest „sens filozoficzny”. Czeżowski pisze na ten temat $w$ duchu praktyki stoickiej:

Uświadomienie sobie swojej przynależności do całego świata - jakie w rzadkich chwilach zastanowienia się nad tym staje się udziałem niewielu tylko ludzi, ale dostępne jest dla wszystkich, którzy zdobędą się na potrzebny wysiłek myśli - uświadamia także sens własnego życia; nabywa ono wówczas treści tak pełnej i bogatej, jak pełny i bogaty jest wszechświat ${ }^{45}$.

Umysłowe podróżowanie i powracanie z mikrokosmosu, czyli własnego wnętrza do wszechświata, otwiera na doświadczenie sensu własnego życia. Jest tak dlatego, że Czeżowski zgodnie z klasycznym pojmowaniem świata uważał, że jest on

41 Tamże.

42 Jan Woleński, Filozoficzna szkoła Lwowsko-Warszawska (Warszawa: PWN, 1985), 287.

43 Tadeusz Czeżowski, „Jak rozumieć »sens życia«”. W: tegoż, Pisma, 172. Na temat pojęcia sensu życia por. Patrycja Kozera-Mikuła, „Sens życia - analiza pojęcia w świetle nauk humanistycznych”. Psychologia Rozwojowa 2 (2020): 9-28.

44 Czeżowski, „Jak rozumieć »sens życia»", 173.

45 Tamże, 174. 
logiczny, czyli uporządkowany. Narzędziami, które mogą przenosić umysł z mikro do makrokosmosu, są pojęcia ogólne oraz metafory ${ }^{46}$.

Pojawia się wobec tego problem wolności jednostki działającej w tak uporządkowanej całości. Polski uczony pisze: „Jakkolwiek bowiem zakładamy, że każde życie jako składnik wszechświata posiada sens, nie jest rzeczą obojętną, jaki ono ma przebieg [...]"47. Czeżowski wskazując na determinanty ludzkiego działania, wyróżnia indywidualne motywacje. To jednostka może kierować swoją uwagą, a dzięki temu kształtować swoje przekonania. Osoba dysponuje też możliwością oceniania, a dzięki temu kształtuje własne emocje i pragnienia. W tym znaczeniu stwierdza filozof - to sam człowiek niezależnie od porządku wszechświata może nadać swojemu życiu głębszy sens.

\section{Wnioski końcowe}

Na podstawie zebranej argumentacji można stwierdzić, że hipoteza została potwierdzona. Pewne elementy etyki i teorii wartości Czeżowskiego mogą stanowić podstawę dla zbudowania przydatnego w warunkach kultury nowych mediów modelu wychowawczego. Po pierwsze, proponowane przez polskiego etyka ćwiczenia ontologiczne mogą pomóc w przywracaniu doświadczenia realnego istnienia. Jest to ważne szczególnie po roku 2020, kiedy proporcje pomiędzy doświadczeniem realności i wirtualności zostały drastycznie zachwiane. Jest to warunek realizacji strategicznego celu rozwojowego, jakim jest dojrzałość. Po drugie, zaprezentowane przez Czeżowskiego ćwiczenia aksjologiczne mogą wspierać proces kształtowania emocji przekonaniowych. Jest to istotne $\mathrm{z}$ uwagi na to, że niemal permanentna i zapośredniczona komunikacja sprzyja ewokowaniu emocji doznaniowych. Wydaje się, że może to być forma profilaktyki minimalizującej ryzyko poważnych zaburzeń emocjonalnych. Po trzecie, przedstawione przez polskiego etyka ćwiczenia filozoficzne mogą nadać głębokie poczucie sensu życia. Dzięki umiejętnemu posługiwaniu się pojęciami ogólnymi oraz narzędziami logiki egzystencja może odkryć cel i wartość. Człowiek uzyskuje wówczas nie tylko spójność charakterologiczną, ale doświadcza swojego życia jako fascynującej przygody będącej integralną częścią historii wszechświata.

Stres z c z e n i e: W artykule poszukuję odpowiedzi na pytanie, czy koncepcja etyki i teorii wartości Tadeusza Czeżowskiego może być przydatna w kulturze, której kształt w dużej mierze określają nowe media. Na podstawie zebranej argumentacji stwierdzono, że pewne elementy systemu Czeżowskiego mogą pomóc w rozwiązaniu niektórych problemów powstających

${ }^{46}$ Por. Pierre Hadot, Filozofia jako ćwiczenie duchowe, tłum. Piotr Domański (Warszawa: Aletheia, 2003), 9-68.

${ }^{47}$ Czeżowski, „Jak rozumieć »sens życia«", 174. 
w tym kontekście. Pierwszym jest zachwianie proporcji pomiędzy doświadczeniem realnym i wirtualnym. Proponuje się tutaj ćwiczenia ontologiczne. Drugim jest nastawienie umysłu na permanentną, zapośredniczoną komunikację. Remedium są ćwiczenia aksjologiczne. Trzecim problemem jest utrata całościowego doświadczenia siebie i świata. Pomocne mogą być tutaj ćwiczenia filozoficzne bazujące na pojęciach ogólnych.

Słow a klu c z ow e: Tadeusz Czeżowski, etyka, aksjologia, kultura nowych mediów, iGen

\section{Bibliografia}

Aboujaoude, Elias. Wirtualna osobowość naszych czasów. Mroczna strona e-osobowości, tłum. Robert Andruszko. Kraków: WUJ, 2012.

Applet, Karolina, Jarzembowska, Marta. „Aktywność twórcza a korzystanie z urządzeń ekranowych przez dzieci w wieku przedszkolnym”. Psychologia Rozwojowa 2 (2020): 31-42.

Binkley, Timothy. „Refigurowanie kultury”. W: Widzieć, myśleć, być. Technologie mediów, red. Andrzej Gwóźdź, 113-143. Kraków: Universitas, 2001.

Brailovskaia, Julia, Ströse, Fabienne, Schillack, Holger, Margraf, Jürgen, „Less Facebook use - More well-being and a healthier lifestyle? An experimental intervention study”. Computers in Human Behavior 108 (2020): 1-9.

Branicki, Wacław. „Indywidualizm w wybranych środowiskach nowych mediów”. Horyzonty Wychowania 24 (2013): 75-91.

Czeżowski, Tadeusz. O metafizyce, jej kierunkach i zagadnieniach. Kęty: Wydawnictwo Antyk, 2004.

Czeżowski, Tadeusz. Pisma z etyki i teorii wartości. Wrocław: Zakład Narodowy im. Ossolińskich, 1989.

Darley, John M., Latané, Bibb. „Bystander intervention in emergencies: Diffusion of responsibility”. Journal of Personality and Social Psychology 4 (1968): 377-383.

Darley, John M., Batson, Daniel C. „»Z Jerozolimy do Jerycha«. Badanie wpływu zmiennych sytuacyjnych i dyspozycyjnych na udzielanie pomocy”. W: Człowiek istota społeczna. Wybór tekstów, red. Elliot Aronson, 65-82. Warszawa: WN PWN, 2002.

Engeln, Renee. Obsesja piękna. Jak kultura popularna krzywdzi dziewczynki i kobiety, tłum. Marta Komorowska. Warszawa: Wydawnictwo Buchmann, 2018.

Flusser, Vilém. Kultura pisma. Z filozofi słowa i obrazu, tłum. Przemysław Wiatr. Warszawa: Wydawnictwo Aletheia, 2018.

Gołuńska, Katarzyna, Miotk-Mrozowska, Magdalena. „Znaczenia nadawane urządzeniu dotykowemu przez rodziców małych dzieci w interakcji ja - dziecko - urządzenie mobilne - badanie eksploracyjne". Psychologia Rozwojowa 2 (2017): 87-110.

Hadot, Pierre. Filozofia jako ćwiczenie duchowe, tłum. Piotr Domański. Warszawa: Wydawnictwo Aletheia, 2003.

Jarymowicz, Maria, Imbir, Kamil. „O dynamice emocji wzbudzanych automatycznie bądź refleksyjnie". W: Dynamika emocji. Teoria i praktyka, red. Dariusz Doliński, Wojciech Błaszczak, 13-30. Warszawa: WN PWN, 2011.

Kozera-Mikuła, Patrycja. „Sens życia - analiza pojęcia w świetle nauk humanistycznych”. Psychologia Rozwojowa 2 (2020): 9-28.

Levinson, Paul. Nowe nowe media, tłum. Maria Zawadzka. Kraków: Wydawnictwo WAM, 2010.

Lind, Georg. How to Teach Moral Competence. Berlin: Logos Verlag, 2019.

Lloyd, Kasey, Pennington, William. „Towards a theory of minimalism and wellbeing”. International Journal of Applied Positive Psychology 5 (2020): 121-136. 
Łukasiewicz, Dariusz. Filozofia Tadeusza Czeżowskiego. Bydgoszcz: Wydawnictwo Akademii Bydgoskiej im. Kazimierza Wielkiego, 2002.

Milgram, Stanley. „Behavioral study of obedience”. Journal of Abnormal and Social Psychology 4 (1963): 371-378.

Prinz, Jesse J. „Emocje jako ucieleśnione oceny”. W: Formy aktywności umysłu. Ujęcia kognitywistyczne. Emocje, percepcja, świadomość, red. Andrzej Klawiter, 37-72. Warszawa: WN PWN, 2008.

Seneka. Myśli, tłum. Stanisław Stabryła. Kraków: Wydawnictwo Literackie, 1987.

Sohn, Sei Yon, Rees, Philippa, Wildridge, Bethany, Kalk, Nicola J., Carter, Ben. „Prevalence of problematic smartphone usage and associated mental health outcomes amongst children and young people: A systematic review, meta-analysis and grade of the evidence". BMC Psychiatry 1 (2019): 356. Spitzer, Manfred. Cyfrowa demencja, tłum. Andrzej Lipiński. Słupsk: Dobra Literatura, 2015.

Spitzer, Manfred. Epidemia smartfonów, tłum. Małgorzata Guzowska. Słupsk: Dobra Literatura, 2021. Turkle, Sherry. Samotni razem. Dlaczego oczekujemy więcej od zdobyczy techniki, a mniej od siebie nawzajem, tłum. Małgorzata Cierpisz. Kraków: WUJ, 2013.

Twenge, Jean M., Campbell, Keith W. „Media use is linked to lower psychological well-being: Evidence from three datasets”. Psychiatric Quarterly 90 (2019): 311-331.

Twenge, Jean M., Spitzburg, Brian H., Campbell, W. Keith. „Less in-person social interaction with peers among US adolescents in the $21^{\text {st }}$ century and links to loneliness". Journal of Social and Personal Relationships 6 (2019): 1892-1913.

Twenge, Jean M. iGen, tłum. Olga Dziedzic. Sopot: Smak Słowa, 2019.

Woleński, Jan. Filozoficzna szkoła Lwowsko-Warszawska. Warszawa: PWN, 1985.

Yaden, David B., Jennifer Claydon, Meghan Bathgate, Belinda Platt, Laurie R. Santos. „Teaching well-being at scale: An intervention study". PLoS ONE 4 (2021): 1-10. 